\title{
REMOTE SENSING OF CITY. DIGITAL DATABASES FOR ARCHITECTURE.
}

\author{
L. Corniello, G. P Lento \\ University of Campania “Luigi Vanvitelli", Department of Architecture and Industrial Design, Aversa, Italy \\ luigi.corniello@unicampania.it, gennaropio.lento@unicampania.it
}

KEY WORDS: City, Remote Sensing, Photogrammetry, Drone, Databases, Digital Technologies

\begin{abstract}
:
The study proposes advanced analyses of the monastic citiy of the western coastal area of the Athos Peninsula in Greece. This research is the result of architectural and environmental survey campaigns conducted since July 2020.

The current bibliographic documentation is limited, and most of the volumes focus on an art and historical description of the paintings in the monasteries, as well as on visitors' travel notes.

Through the consolidated phases of the discipline of representation, such as digital surveying, point clouds and the processing of flat surfaces, a journey of knowledge of the third arm of the Chalkidiki peninsula is proposed with regard to the religious architecture considered as micro-cities.

The initial part of the research was developed with photographic documentation from the sea, while in subsequent survey phase of the monasteries on the west coast was carried out.

The instrumental survey activities, carried out with the help of quadrihelix drones and terrestrial photogrammetry, concerned the Monastery of St. Dionysius, the Monastery of Xeropotmus, the Monastery of Zographos, the Monastery of Dochiario, the Monastery of Simonpetra, the Monastery of St. Paul, the Monastery of Xenophon, the Monastery of St. Gregory, the Monastery of St. Pantaleimon and the Monastery of Konstamonitou.

The research aims to expose, for the first time, the unpublished instrumental surveys carried out in the Athos community, which has been averse to the access of tourists and curious people for centuries.
\end{abstract}

\section{INTRODUCTION}

The paper presents the results of architectural survey campaigns of religious city along the western coastal strip of the Mount Athos peninsula. An autonomous territory within the Hellenic Republic but with a special self-governing statute, located at the last of the three peninsulas of the region called Chalkidiki. (Muresu, 2014)

The theme of the city can be seen in the geometric forms and the public and political functions assumed by the monasteries. Social activities are governed independently in the individual structures while taking into account the monastic rules.

The current bibliographical documentation focuses, for the most part, on an art and historical description of the paintings in the monasteries, as well as on the travel notes of visitors who have climbed their peaks and steep paths and is scanty in graphic documentation and surveys of the architectural volumes.

Many famous travellers (architects, philosophers, writers, directors) have drawn inspiration for their works from the slopes of the Holy Mountain: Umberto Eco, famous novel The Name of the Rose was inspired by his journey to Athos. Le Corbusier also visited the Mount and some references can be found in his 1960 work, the Catholic Monastery of Tourette in Lyon, France, whose structure can be compared to the monastic complex of Dionisiou.

Over the centuries, the monastic community of Athos, dedicated to the hermitic life, has preserved the social traditions of the approximately 1500 Orthodox monks and the architectural geometry of the community buildings, churches, service structures, dormitories and solitary cells aggregated in vast complexes similar to religious city.

\section{THE PROCESS OF REMOTE SENSING OF ARCHITECTURE AND CITY}

The consolidated phases of the discipline of representation, such as digital surveying, point clouds, processing of flat surfaces and 3D modelling, have enabled a journey of knowledge of the third arm of the Chalkidiki peninsula, both with regard to the religious architecture and to the current and historical functions of the ten Monasteries under research.

The research was developed, in the initial part, with photographic documentation taken from the sea, in order to create an appropriate illustrative campaign to document the artefacts. In a second phase, after the difficult visa procedures for access to the sites, the survey of the Monasteries on the west coast was carried out.

Of great importance is the design of the sockets, the definition of the shooting points from which the measurements are taken. This project took into account the actual dimensions of the Monasteries both for the phase carried out from the sea and for the subsequent surveys from land. A survey project was then drawn up which required greater attention as it was necessary to superimpose the images and align them correctly. The characterisation of the shots allowed the definition of some image filtering procedures in order to establish the greatest reduction in noise and the maintenance of the geometric configuration given by the shapes of the Monasteries. (Apollonio, 2010)

The size of the architectural detail, often consisting of fixtures, wall facings and balconies, constituted a further parameter for the realisation of the point clouds both on the basis of the optics used and in relation to the mesh established for the survey phases. 

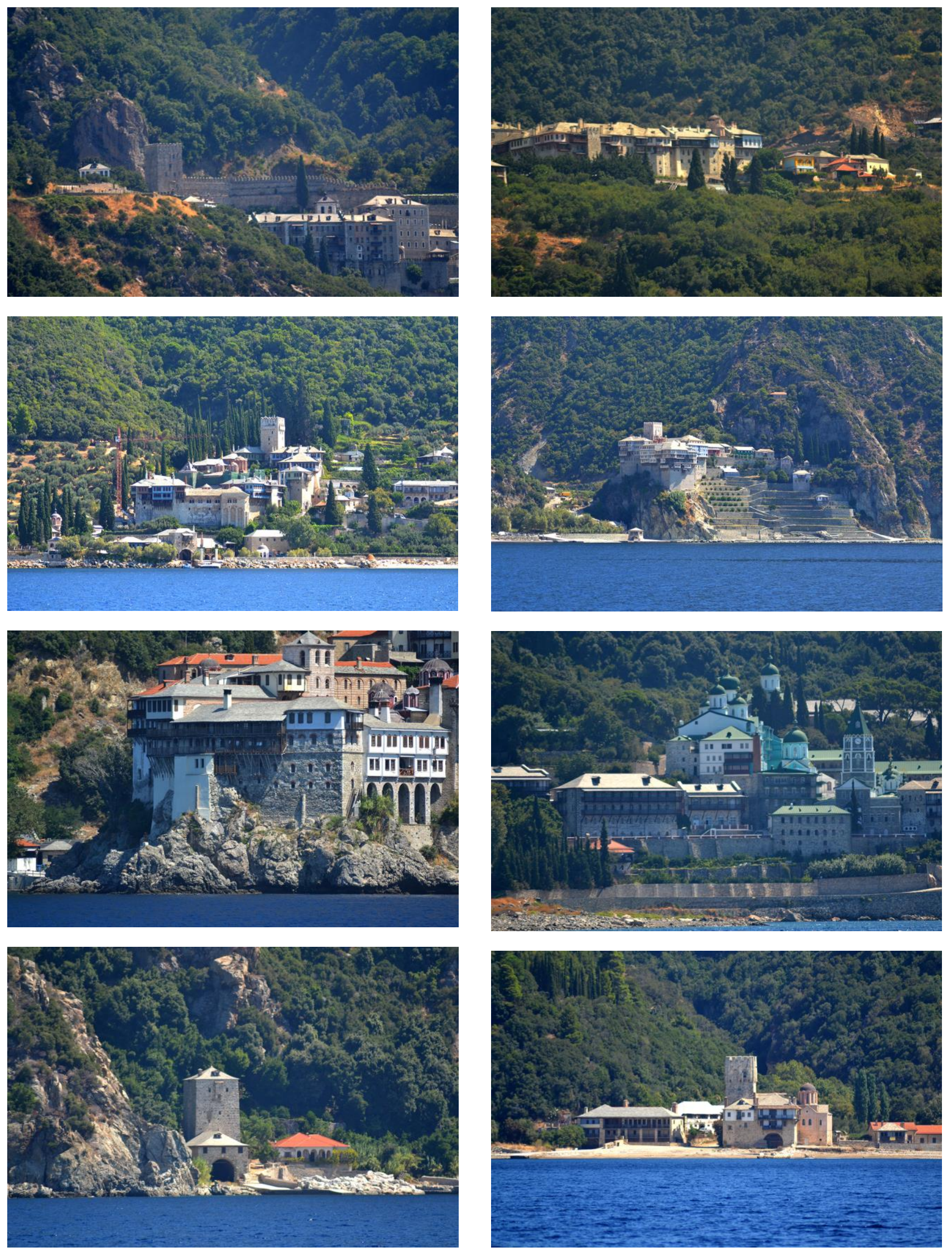

Figure 1. Photographic documentation of the Monasteries from the sea made in July 2020. 


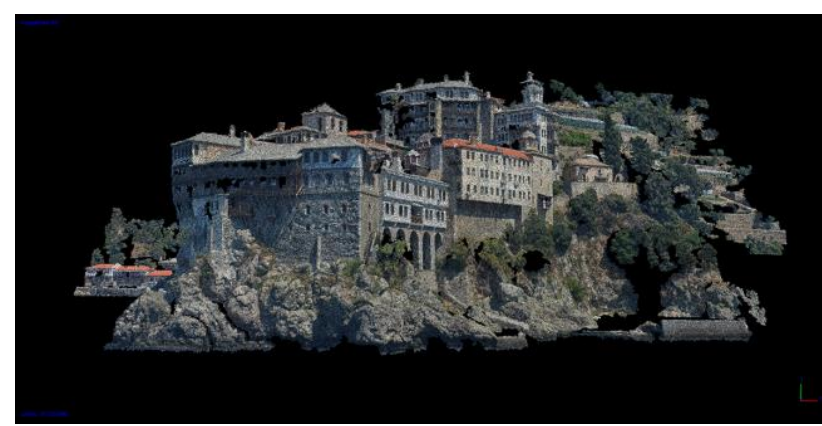

Figure 2. The Monastery of St. Gregorio. Cloud of points.

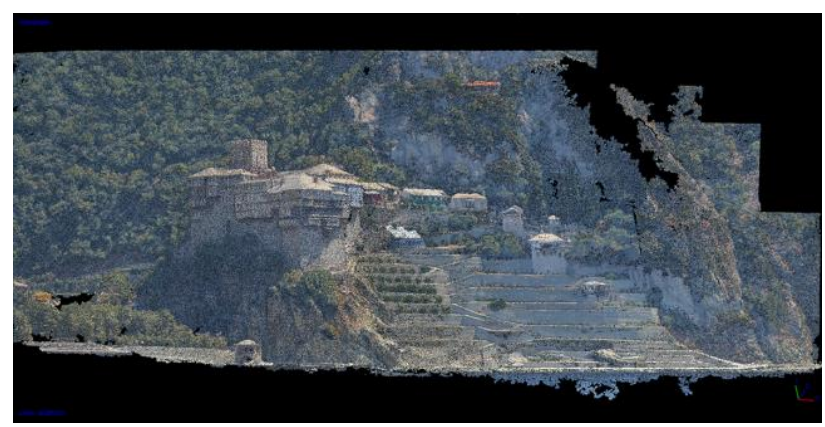

Figure 3. The Monastery of St. Dionysius. Cloud of points.

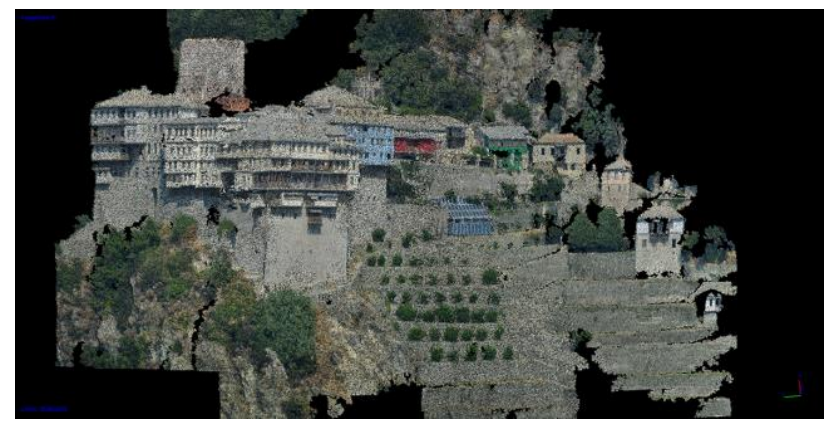

Figure 4. The Monastery of St. Dionisio. Cloud of points.

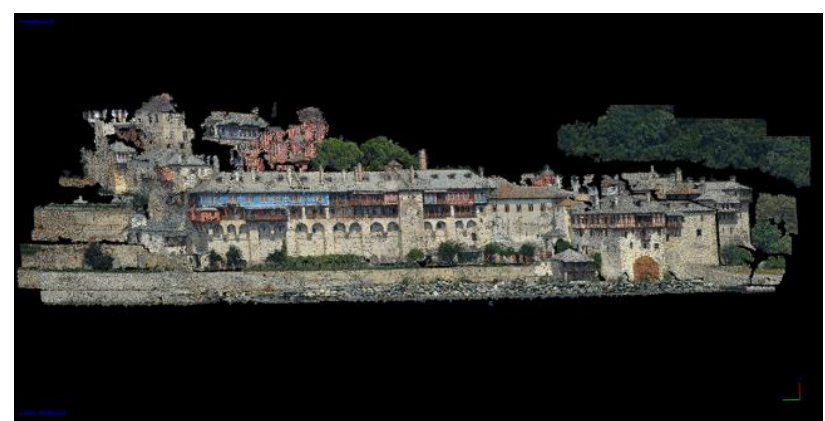

Figure 5. The Monastery of Xenophontos. Cloud of points.

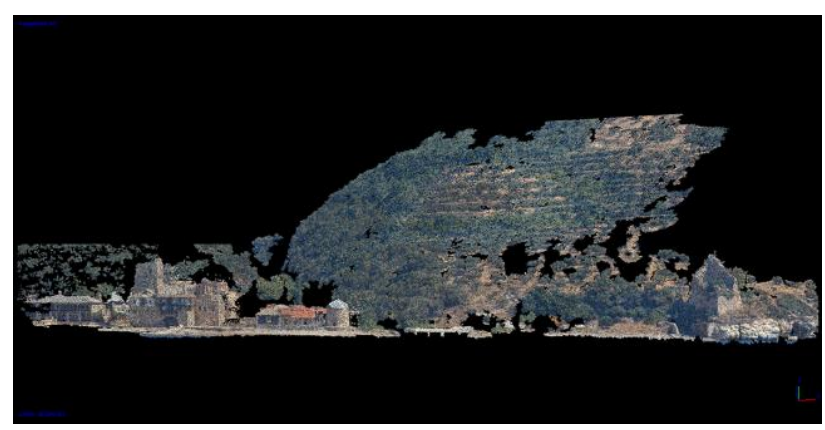

Figure 6. The Monastery of Zograph. Cloud of points.

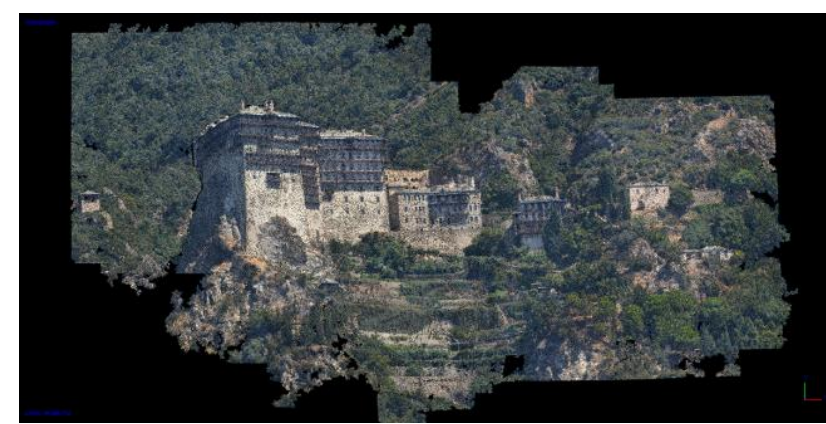

Figure 7. The Monastery of Simonpetra. Cloud of points.

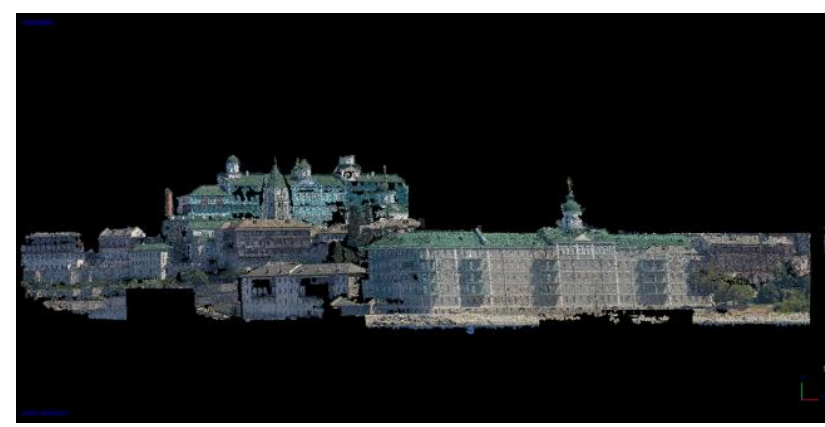

Figure 8. The Monastery of St. Pantaleimon. Cloud of points.

In relation to the purpose of the survey, graphic-geometric documentation, the dimensional and occlusion characteristics, the reflection of the material and the detail relationship were taken into account. The lack of freedom of movement, caused by the filming carried out by boat, for which it was necessary to take into account the relative oscillation due to the sea waves, greatly influenced the survey campaign and the processing of the data collected. The captured images were interpolated with measurements taken at three different points. The survey was carried out both from the centre, perpendicular to the individual Monasteries, and the side points in order to collect the greatest number of triangles for the creation of the digital survey model. Following the sea and land survey campaign, processing of the collected data was carried out. Of great importance is the alignment of the images through the digital software. In order to control the error, the overlap was calculated to the extent of $40 \%$ between one image and another with a symmetrical view from two vertices towards the same point of capture. (Remondino, 2011)

The images taken from the sea shots did not show any problems of poor overlap in mesh generation, as they were both numerically suitable for the light condition. The meshes were merged into a single image with polygonal characteristics. This activity resulted in the creation of merge images of the point cloud. The geometries obtained were realised using the maximum density of the polygon vertices, reducing the automatic control of the surfaces to a maximum. (Apollonio, 2010)

The editing phase, on the other hand, was developed by marking and eliminating typological errors relating to the acquisition of the images, mainly for the phase carried out by the boat, and the subsequent point cloud alignment processes. Subsequently, although to a lesser extent, manual intervention was necessary to close the gaps present in the less exposed surfaces.

The point cloud created was then checked for external noise caused by the multiple environmental conditions present on site. Subsequently, the plans and main sections were created in order to document the monastic complexes of Athos. 


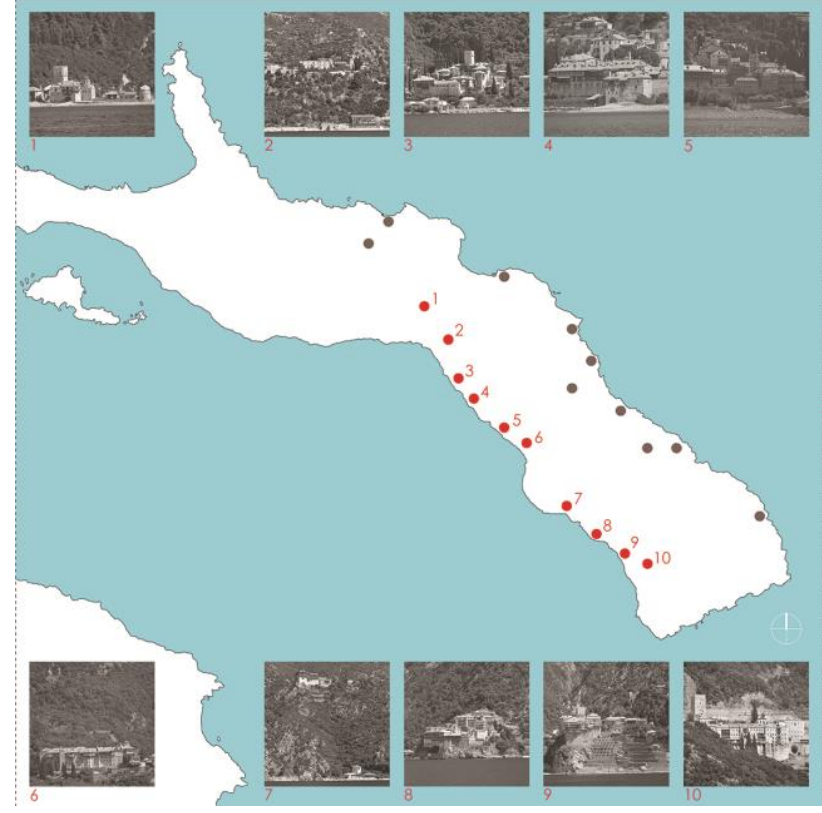

Figure 9. The Monasteries of Mount Athos. Planimetric identification of the Monasteries in red.

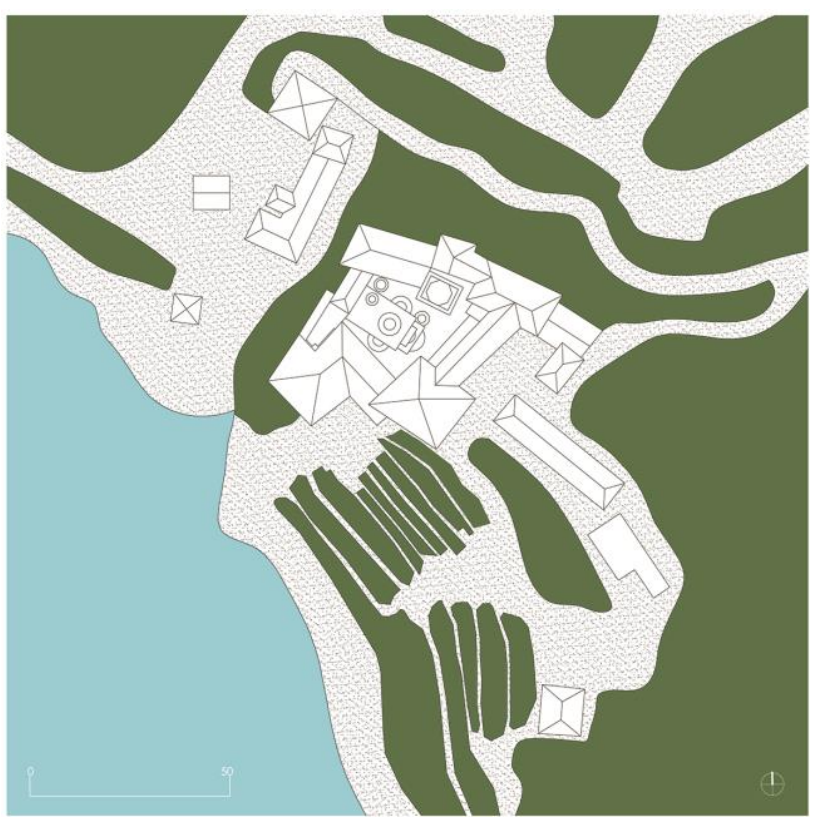

Figure 10. The Monastery of St. Dionisio. General plan.

\section{ARCHITECTURE AND FUNCTION}

In the definition of research on religious micro-cities, the study of the spaces in which monastic life takes place is of particular interest. They are complex places in terms of form and position. Simple forms and complex geometries aggregate to follow the slopes of the mountain.

The activities concerned the Monastery of St. Dionysius, the Monastery of Xeropotmus, the Monastery of Zographus, the Monastery of Dochiarius, the Monastery of Simonpetra, the Monastery of St. Paul, the Monastery of Xenophon, the Monastery of St. Gregory, the Monastery of St. Pantaleimon and the Monastery of Konstamonitou.

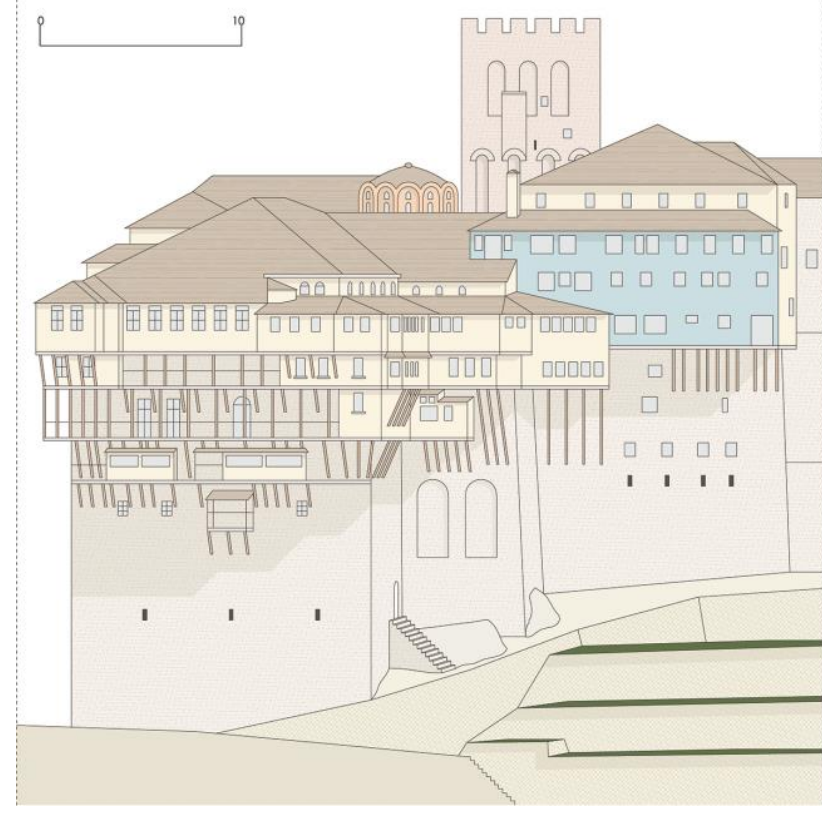

Figure 11. The Monastery of St. Dionisio. Detail of the western elevation

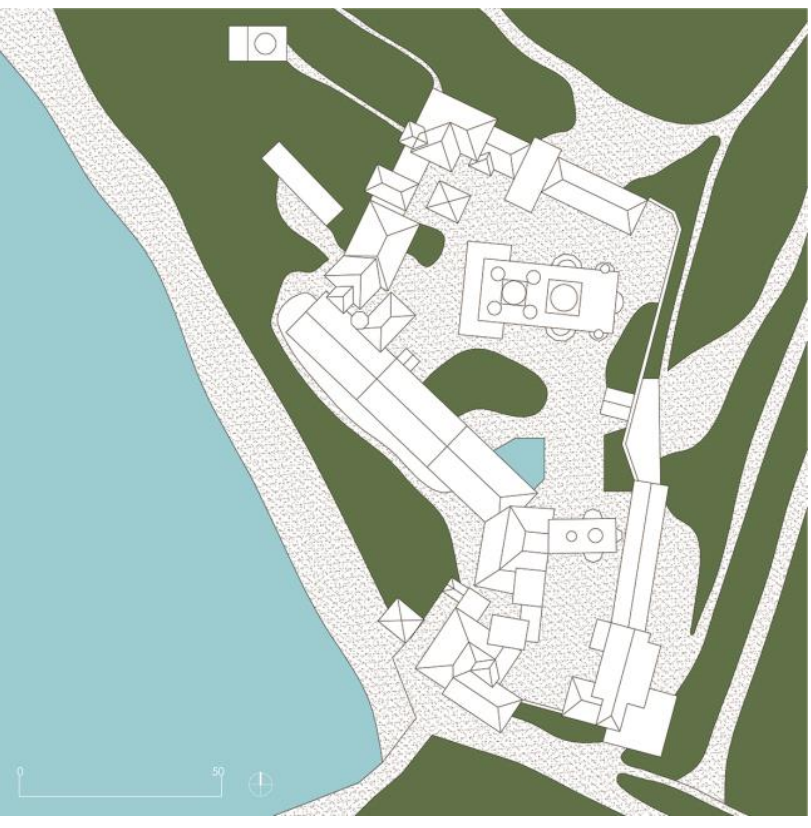

Figure 12. The Monastery of Xenophontos. General plan.

The Monastery of Dionisiou, built in the middle of the $14^{\text {th }}$ Century by the monk Dionysious of Koryssos, was destroyed by fire in 1535 and subsequently rebuilt, retaining its architectural form to this day. The structures, built on a spur of rock overlooking the sea, are smaller than the floor space of the other complexes. The monastery is characterised by a central church surrounded by several chapels with frescoes and a refectory completed in 1603. Of particular interest is the defensive tower, built in 1520, which currently houses the monastery's precious library with numerous works of art including icons and miniature manuscripts.

The Monastery of Xenophontos is located by the sea, between the structures of Docheiariou and St Panteleimonos, and is dedicated to St George. 


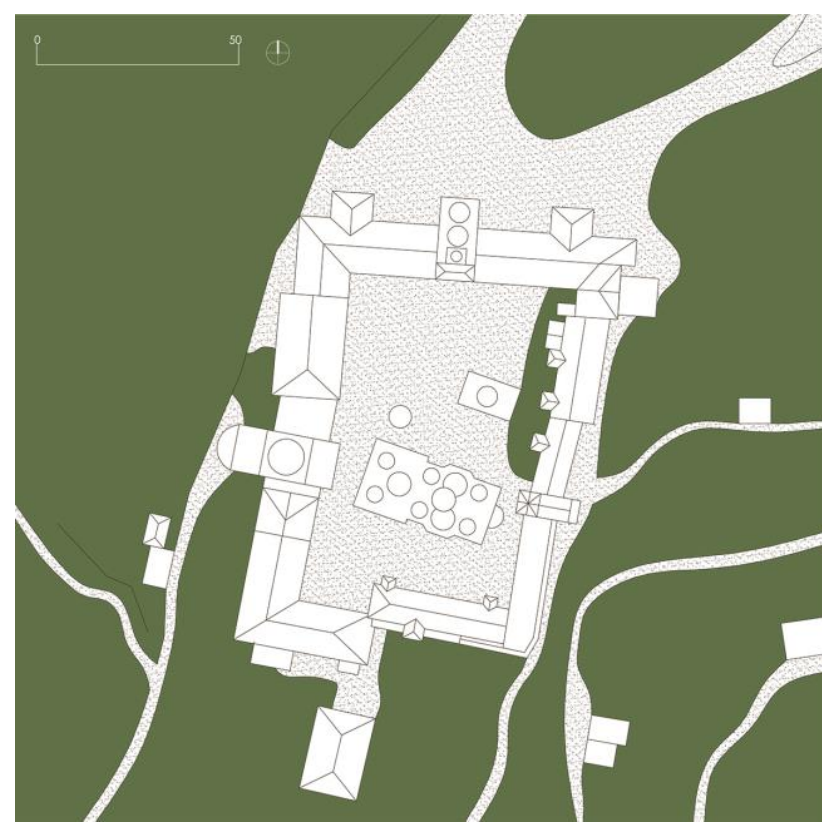

Figure 13. The Monastery of Zografo. General plan.

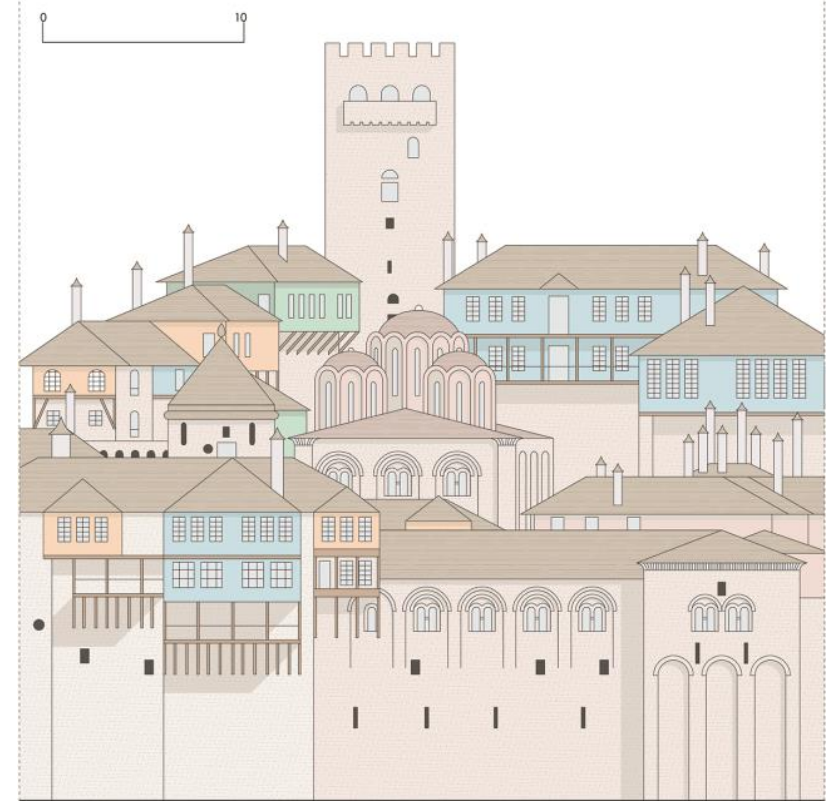

Figure 14. The Monastery of Dochiariou. Detail of the western elevation.

In the historical bibliography it is mentioned in the $11^{\text {th }}$ Century, when after a long commercial and cultural activity it was destroyed and rebuilt. The sea-facing part of the building has a large entrance opening, topped by four floors, one of which is attic. The lower part of the building is characterised by a stone structure with arches and buttresses surmounted by wooden galleries coloured red and blue. Of great interest is the library with 300 manuscripts, over 4000 books and numerous mosaic icons.

The Monastery of Zografo, traditionally founded in the $10^{\text {th }}$ Century, is dedicated to St George and situated on a slope on the south-west side of the Mount Athos peninsula. In the late Byzantine period, it was destroyed by pirates and rebuilt with the financial support of Eastern European rulers.

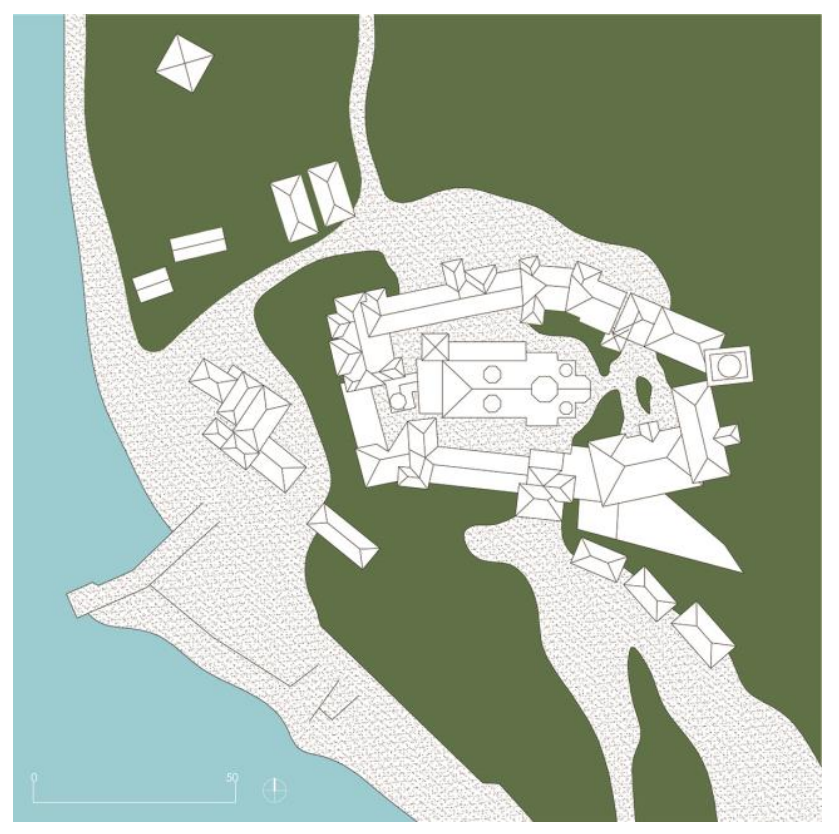

Figure 15. The Monastery of Dochiariou. General plan.
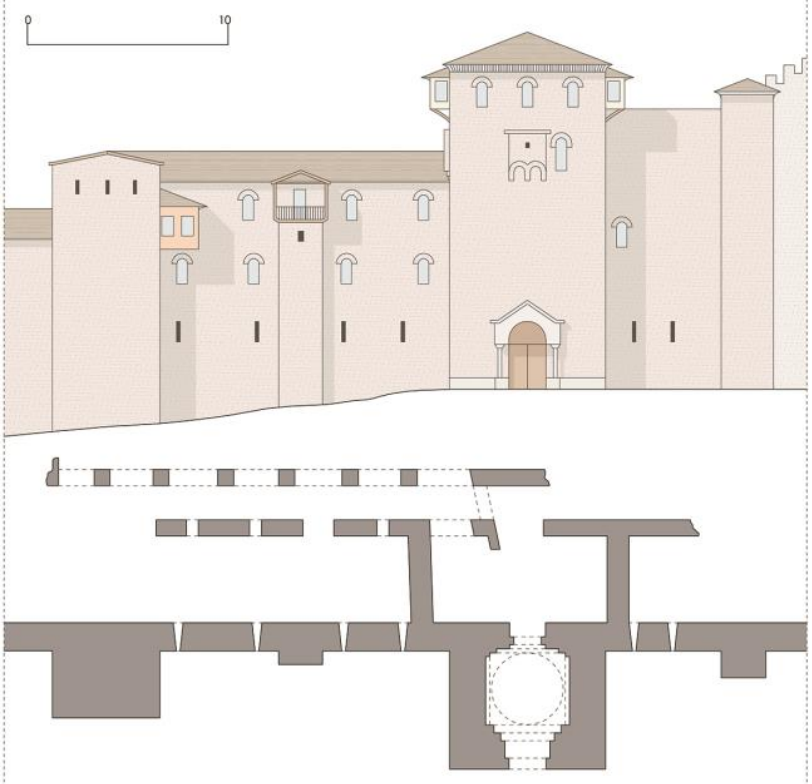

Figure 16. The Monastery of Dochiariou. Detail of the western elevation.

For this reason, the majority of the resident monks came from Bulgaria, Serbia and to some extent, Greece. The volumes in the central courtyard are covered with copper-plated zinc domes. There are also two workshops for painting and making religious icons and a library with 126 manuscripts in Greek and 388 in Slavic. The seaside Monastery of Dochiariou was founded in the second half of the $10^{\text {th }}$ Century. At present, the structure can be reached by means of a dock for small and medium-sized boats to supply non-self-produced goods. The monastic complex develops on the slope of the mountain with different geometric shapes such as the parallelepipeds of the main volumes, the spheres and hemispheres of the domes of the churches and chapels, the pyramids and cones of the roofs. 


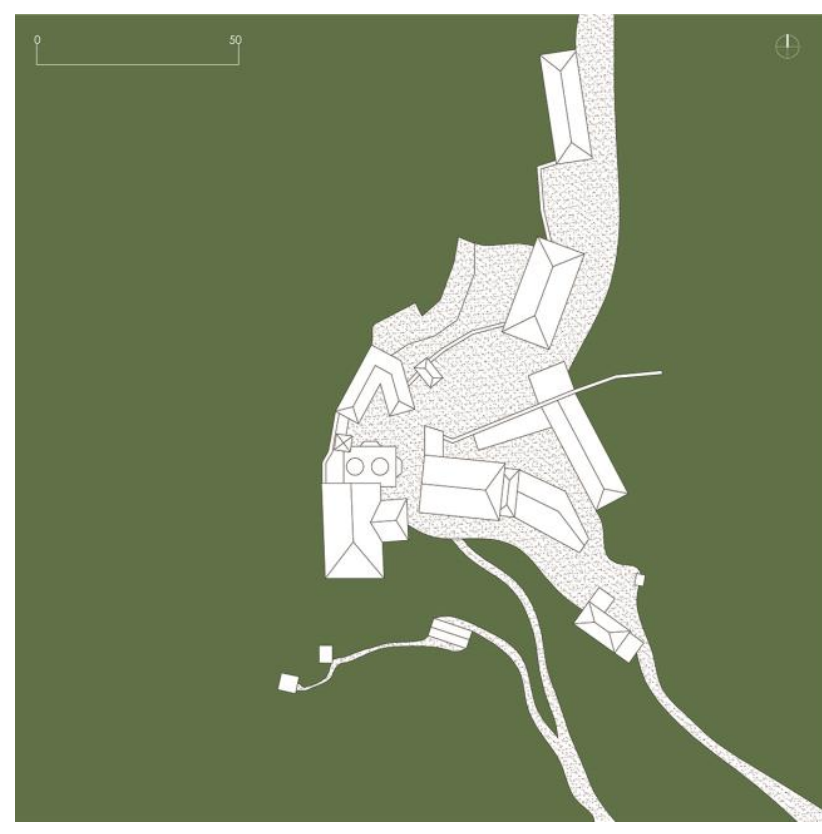

Figure 17. The Monastery of Simonpetra. General plan.
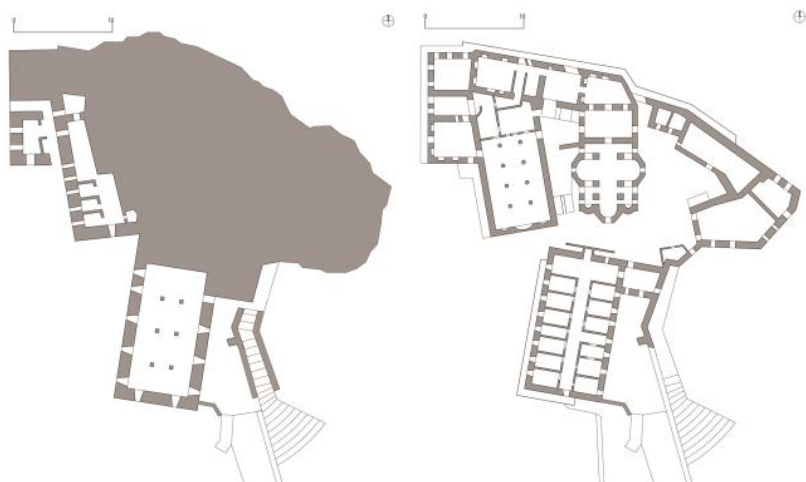

Figure 18. The Monastery of Simonpetra. Planimetry of the hypogeum and planimetry ground floor.

Of particular note are the two refectories positioned parallel to the coastline, with the old refectory by the sea, dating from 1675 , and the new one on the hill from 1700 , overlooked by the Katholikon, the main church built on the remains of the walls of an older religious building. The monastery also has a watchtower and a library with about 900 manuscripts.

The Simonpetra Monastery is a majestic seven-storey building dedicated to the birth of Christ. The structure is 230 metres above sea level and consists of two architectural complexes, one downstream, which serves as a landing place for boats from the nearby Ouranopoli, and the other upstream, where the monks live and pray. The building by the sea, with a small harbour and boathouse, has a stone watchtower. In a panoramic position, facing south, the Monastery is composed of two built portions: the first with the church, the refectory and a tower; the second, instead, entirely used as a residence for the monks with cells and services. Over the centuries, the building was destroyed by numerous fires and rebuilt several times through donations from Russia.

The Monastery of St Paul, dedicated to the presentation of Christ in the Temple, was destroyed and rebuilt many times over the centuries, and this architectural stratification can be seen in the shapes of the buildings, which date back to different periods.

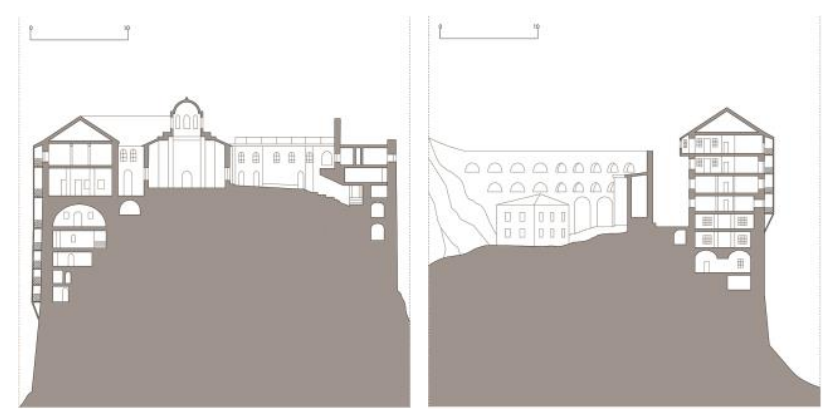

Figure 19. The Monastery of Simonpetra. Cross-section and longitudinal section

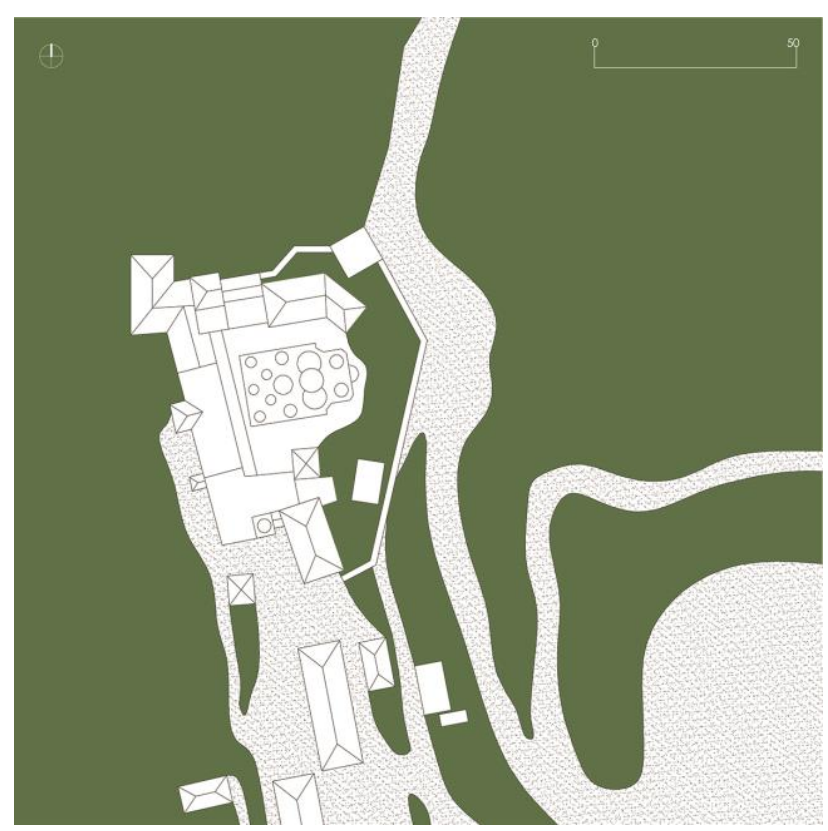

Figure 20. The Monastery of St Paul. General plan.

The religious complex, currently attended by a community of 30 monks, has 12 prayer chapels, the most important of which is the one dedicated to St George, with frescoes of the Cretan school dating back to 1555 . Of great interest is the library containing 494 manuscripts and a total of about 12.500 books.

The Monastery of Grigoriou, currently inhabited by a brotherhood of 70 monks, is built by the sea, on the southwest side of the peninsula, between the monasteries of Dionysiou and Simonpetra and is dedicated to St Nicholas. The fifth building by the sea has a parallelepiped volume characterised by projecting wooden galleries decorated with pillars and arches. The structure is characterised by two internal courtyards and an imposing wall at the back that protects the Monastery from landslides from the mountain. The entrance courtyard, facing north, houses the monk cells and acts as a filter for the second courtyard, characterised by the presence of the main church dating back to the middle of $18^{\text {th }}$ Century.

The Monastery of St. Panteleimon, built on a flat area by the sea, consists of several buildings: a rectangular main body with several structures such as churches and chapels; an L shaped building that follows the coastline. The latter serves as a hermitage for monks and pilgrims visiting or praying. The Monastery has 15 chapels and numerous spaces for making sacred objects, such as a carpentry shop. 


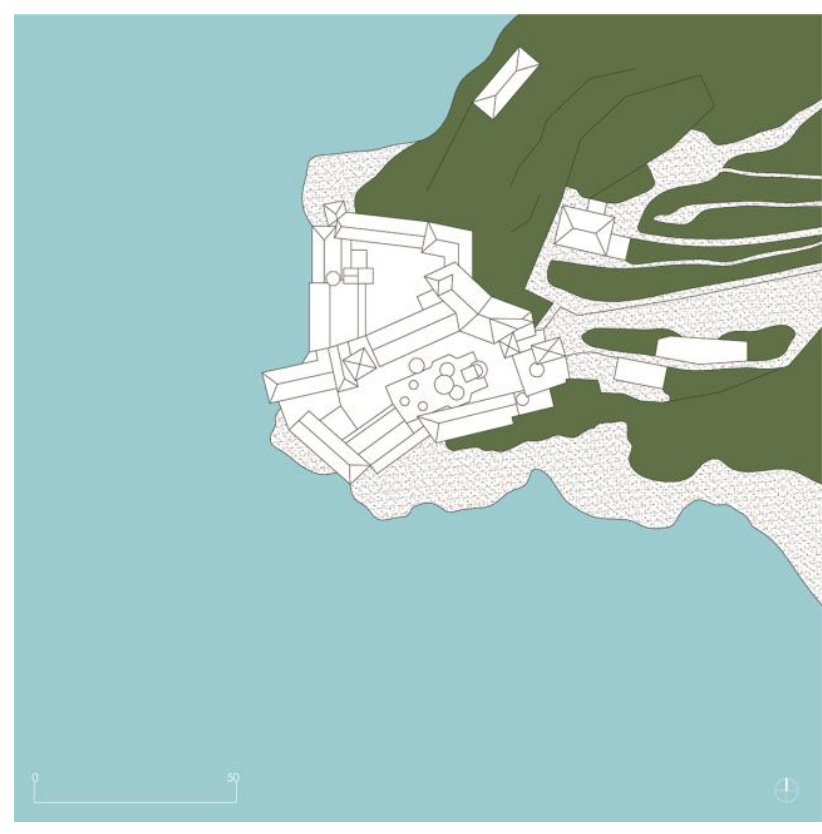

Figure 21. The Monastery of St. Gregory. General plan.

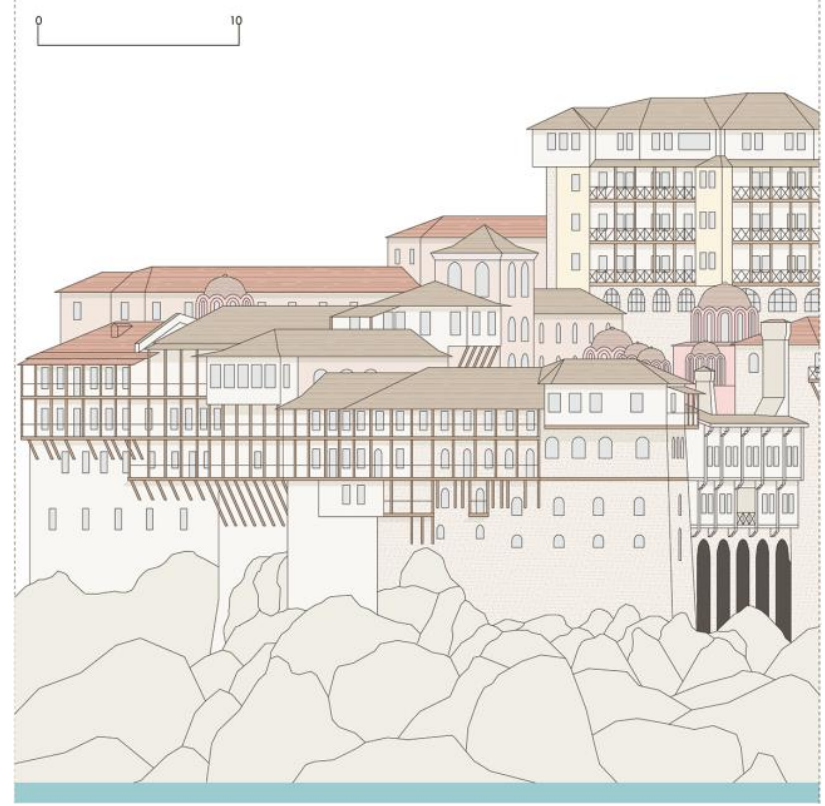

Figure 22. The Monastery of St. Gregory. Detail of the western elevation.

The library contains 1320 Greek and 600 Slavic manuscripts and over 20000 Greek and Russian books. Of great interest is the use of red and green colours in the roofs, earthenware tiles and copper surfaces that contrast with the white of the walls adorned with wooden balconies and galleries.

The Konstamonitou Monastery is located in a forest, 200 metres above sea level, 50 minutes away from the coast. The construction of the small building with a central courtyard is due to a hermit who wanted to spend his time in solitude and prayer in contact with nature. The present complex has undergone numerous changes due to reconstructions following fires: those of the $14^{\text {th }}$ Century, 1360 and 1433. Following the reconstructions, the wall face is in local stone and the roof in red brick, reducing the presence of wood on the facade and roof

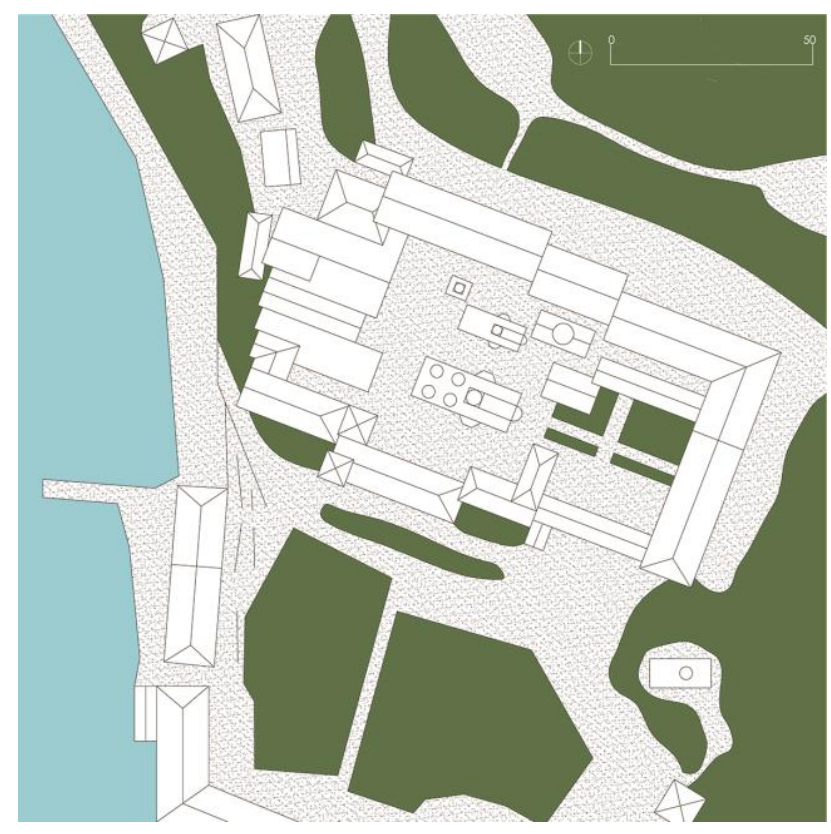

Figure 23. The Monastery of St. Pantaleimon. General plan.

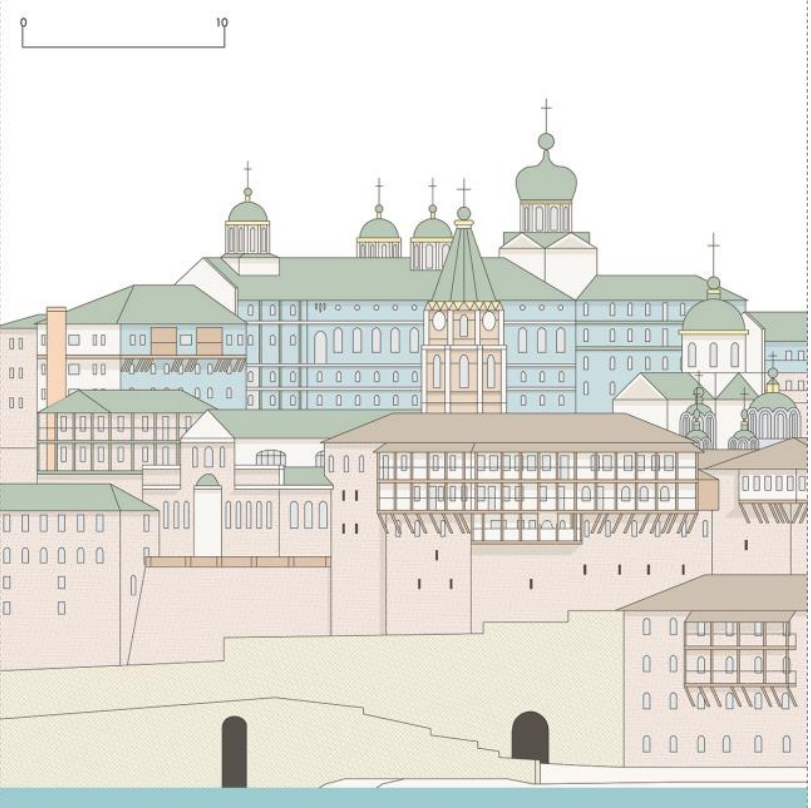

Figure 24. The Monastery of St. Pantaleimon. Detail of the western elevation.

to a minimum. In the courtyard is the main church with six copper-clad roof lanterns and a small library building.

\section{CONCLUSIONS}

The investigations carried out analysed the architectural languages and forms of the micro-cities of Athos.

By the use of photogrammetry, it was possible to detect the buildings unreachable from the ground. The survey phases made it possible to develop an original graphic documentation for the knowledge of the places.

Of great interest is the operational process illustrated both on the basis of the problems that emerged and the solutions adopted in the knowledge phases. 


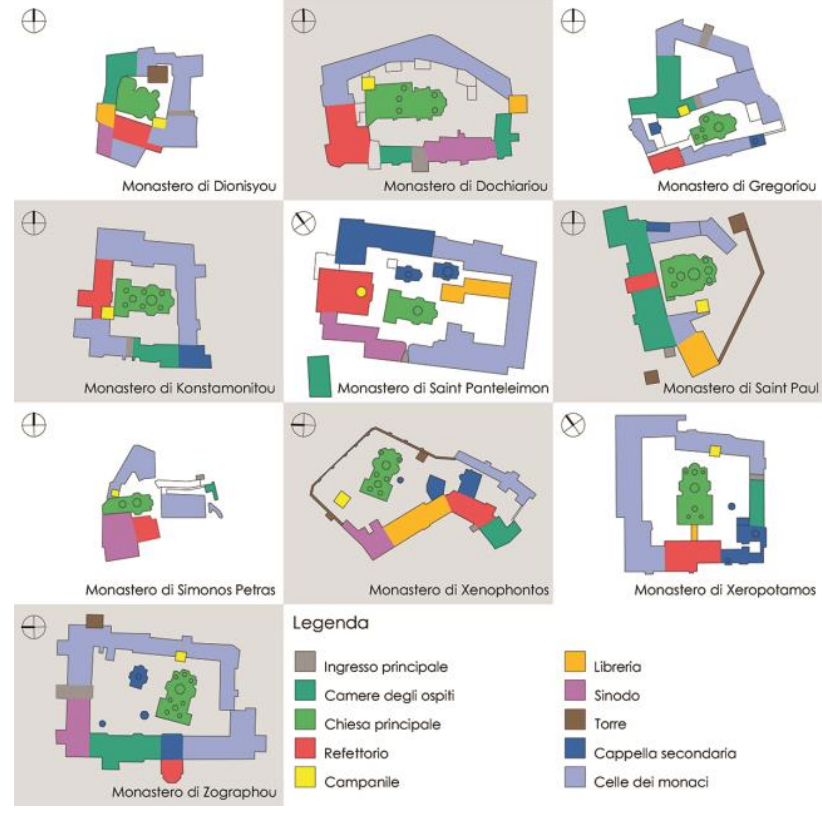

Figure 25. The Monasteries of Mount Athos. Graphic diagrams of the compared functions.

The research exposes, for the first time, the unpublished instrumental surveys carried out in the community of Athos, which for centuries has been denied access to scholars, tourists and the curious.

The instrumental survey activities, carried out with the aid of quadrihelix drones and terrestrial photogrammetry, concerned the western part of the third Chalkidiki peninsula: the Monastery of St. Dionysius, the Monastery of Xeropothemus, the Monastery of Zographos, the Monastery of Dochiario, the Monastery of Simonpetra, the Monastery of St. Paul, the Monastery of Xenophon, the Monastery of St. Gregory, the Monastery of St. Pantaleimon and the Monastery of Konstamonitou.

The research is configured as a methodological process to be implemented at both small and large scales for the survey of historical complexes.

Remote sensing systems from drones have made it possible to carry out flights in areas uncovered by the range of normal cameras, guaranteeing an overall knowledge of the property.

The data collected constitutes a well-stocked database of metric, artistic and architectural information on the individual Monasteries that can be used for future interventions. In addition to this activity, it is of particular interest to be possible to catalogue the architecture, the landscape and the cities in order to provide both ordinary and extraordinary maintenance for management and social development.

\section{REFERENCES}

Amini Amirkolaee, H., Arefi, H. 2019. 3D change detection in urban areas based on dcnn using a single image, Int. Arch. Photogramm. Remote Sens. Spatial Inf. Sci., XLII-4/W18.

Amoruso, G., Apollonio, F., I., Remondino, F. 2010. Caratterizzazione strumentale di sensori attivi a tempo di volo e a triangolazione, Pisa: Scuola Normale di Pisa.

Apollonio, F., I. 2010. La modellazione digitale. Bologna: Clueb.
Barba, S., Cardone, V. 2013. Modelli grafici dell'architettura e del territorio. Santarcangelo di Romagna: Maggioli.

Bertocci, S., Bigongiari, M., Becherini, P., Cottini, A. 2020. Architectural heritage building in the state of São Paulo: survey and digital documentation of a Jesuit mission, Int. Arch. Photogramm. Remote Sens. Spatial Inf. Sci., XLIV-M-1-2020.

Burridge, P. 1996. Architectural development of the Athonite Monastery. In Mount Athos and Byzantine Monasticism. Brookfeld: Ashgate Publishing Company.

Capuani, M. 1988. Monte Athos. Baluardo monastico del Cristianesimo orientale. Novara: Europìa.

Capuani, M. 1997. Il patrimonio artistico. In Athos, le fondazioni monastiche, un millennio di spiritualità $e$ arte ortodossa. Milano: Jaca Book.

Corniello, L. 2020. Photogrammetric $3 d$ information systems for the management of models of cultural heritage, Int. Arch. Photogramm. Remote Sens. Spatial Inf. Sci., XLIV-4/W1-2020.

Crisan N. 2016. Athos. The Holy Mountain. Suceava: Accent Print.

Della Valle, M. 2007. Costantinopoli e il suo impero. Arte, architettura, urbanistica nel millennio bizantino. Milano: Jaca Book.

Dipasquale, L., Montoni, L., Manzi, A., Mecca, S. 2020. The Chorá of Patmos (Greece): analysis of architectural heritage, identification of risks and assessment of impacts, Int. Arch. Photogramm. Remote Sens. Spatial Inf. Sci., XLIV-M-1-2020.

Farides C. 2010. Monte Santo. Il giardino della Madonna. Salonicco: Rekos.

Manfredini, A., M., Remondino, F. 2010. Modellazione 3D da immagini. Pipeline fotogrammetrica. Pisa: Scuola Normale di Pisa.

Mateus, L., Ferreira, V., Aguiar, J., Pacheco, P., Ferreira, J., Mendes, C., Silva, A. 2020. The role of $3 d$ documentation for restoration interventions. the case study of Valflores in Loures, Portugal, Int. Arch. Photogramm. Remote Sens. Spatial Inf. Sci., XLIV-M-1-2020.

Menna, F., Remondino, F., Maas, H.G., 2016. Sensors and Techniques for $3 D$ Object Modeling in Underwater Environments. MDPI Publisher.

Muresu M. 2014. Architettura sacra mediobizantina dal Monte Athos (Grecia), il caso di Ravdouchos. In ArcheoArte, n 3.

Pentzikis, G. N. 2003. Mount Athos. Athens: print.

Remondino, F. 2011. Rilievo e modellazione $3 D$ di siti $e$ architetture complesse, in DisegnareCon, dicembre 2011.

Trumler G. 2009. Athos. L'orto della Madonna. Peania: Adam Editions. 